\title{
Organic-rich sediments in ventilated deep-sea environments: Relationship to climate, sea level, and trophic changes
}

\author{
P. Bertrand, ${ }^{1}$ T. F. Pedersen, ${ }^{2}$ R. Schneider, ${ }^{3}$ G. Shimmield, ${ }^{4}$ E. Lallier-Verges, ${ }^{5}$ \\ J. R. Disnar, ${ }^{5}$ D. Massias, ${ }^{1}$ J. Villanueva, ${ }^{1}$ N. Tribovillard, ${ }^{6}$ A. Y. Huc,${ }^{7}$ X. Giraud, ${ }^{1}$ \\ C. Pierre, ${ }^{8}$ and M.-T. Vénec-Peyré ${ }^{9}$
}

Received 24 March 2000; revised 18 July 2001; accepted 6 December 2001; published 21 February 2003.

[1] Sediments on the Namibian Margin in the SE Atlantic between water depths of $\sim 1000$ and $\sim 3600 \mathrm{~m}$ are highly enriched in hydrocarbon-prone organic matter. Such sedimentation has occurred for more than 2 million years and is geographically distributed over hundreds of kilometers along the margin, so that the sediments of this region contain a huge concentrated stock of organic carbon. It is shown here that most of the variability in organic content is due to relative dilution by buried carbonates. This reflects both export productivity and diagenetic dissolution, not differences in either water column or bottom water anoxia and related enhanced preservation of organic matter. These observations offer a new mechanism for the formation of potential source rocks in a well-ventilated open ocean, in this case the South Atlantic. The organic richness is discussed in terms of a suite of probable controls including local wind-driven productivity (upwelling), trophic conditions, transfer efficiency, diagenetic processes, and climaterelated sea level and deep circulation. The probability of past occurrences of such organic-rich facies in equivalent oceanographic settings at the edge of large oceanic basins should be carefully considered in deep offshore exploration. INDEX TERMS: 1615 Global Change: Biogeochemical processes (4805); 4219 Oceanography: General: Continental shelf processes; 4267 Oceanography: General: Paleoceanography; 4845 Oceanography: Biological and Chemical: Nutrients and nutrient cycling; KEYWORDS: petroleum source rocks, coastal upwelling, deep-sea sediments, quaternary climate, Southwestern African Margin

Citation: Bertrand, P., et al., Organic-rich sediments in ventilated deep-sea environments: Relationship to climate, sea level, and trophic changes, J. Geophys. Res., 108(C2), 3045, doi:10.1029/2000JC000327, 2003.

\section{Introduction}

[2] Classical views for the deposition of oil-prone and organic-rich sediments in deep-sea environments invoke two principal types of oceanographic and sedimentologic settings. The first is confined basins in which stratified oxygendepleted waters lead to anoxic preservation of organic matter in the water column and in underlying sediments [de Graciansky et al., 1984; Demaison and Moore, 1980]. The

\footnotetext{
${ }^{1}$ Departement de Géologie et Océanographie, UMR-CNRS, Université de Bordeaux I, Talence, France.

${ }^{2}$ Oceanography, Earth and Ocean Sciences, University of British Columbia, Vancouver, British Columbia, Canada.

${ }^{3}$ Fachbereicht Geowissenschaften, Universität Bremen, Bremen, Germany.

${ }^{4}$ Dunstaffnage Marine Laboratory, Oban, UK.

${ }^{5}$ Sédimentologie et Diagenèse de la Matière Organique, UMR, Université d'Orléans, Orléans, France.

${ }^{6}$ Sédimentologie et Géodynamique, UMR-CNRS, Université de Lille 1, Villeneuve d'Ascq ce, France.

${ }^{7}$ Institut Français du Pétrole, Rueil Malmaison, France.

${ }^{8}$ Laboratoire d'Océanographie Dynamique et de Climatologie, Université Pierre et Marie Curie, Paris, France.

${ }^{9}$ Muséum National d'Histoire Naturelle, Paris, France.

Copyright 2003 by the American Geophysical Union. 0148-0227/03/2000JC000327
}

second is an open ocean setting where episodic mass transfers due to slope sediment instability lead to the rapid burial of outer-shelf- and upper slope-derived organic matter and its consequent preservation due to limited oxic or anoxic degradation [Huc, 1988; Stow, 1987]. Other studies have shown, however, that organic matter in modern deep-sea sediments may occur in high amounts where oxygen is not significantly depleted [Pedersen and Calvert, 1990; Martinez et al., 1996; Prakash Babu et al., 1999]. Moreover, studies on Jurassic anoxic sediments showed that productivity more than anoxia may have been the primary control on organic content variability [Bertrand and Lallier-Verges, 1993; Ramanampisoa and Disnar, 1994].

[3] Another mechanism may account for the occurrence of organic-rich deposits, namely relative variations in the magnitude of nonorganic burial fluxes. Here we explore this alternative hypothesis, focusing on pelagic deposits from the Namibian Margin that show strong relative variations between organic carbon and carbonate contents.

[4] The study focuses on two giant piston and two gravity cores raised along two bathymetric transects perpendicular to the margin (Figure 1) within the depth range $\sim 1000$ to $\sim 3600 \mathrm{~m}$. Piston cores MD96-2086 (3606 m water depth) and MD96-2087 (1028 m water depth) were collected along the southern (Lüderitz) transect during the NAUSICAA- 


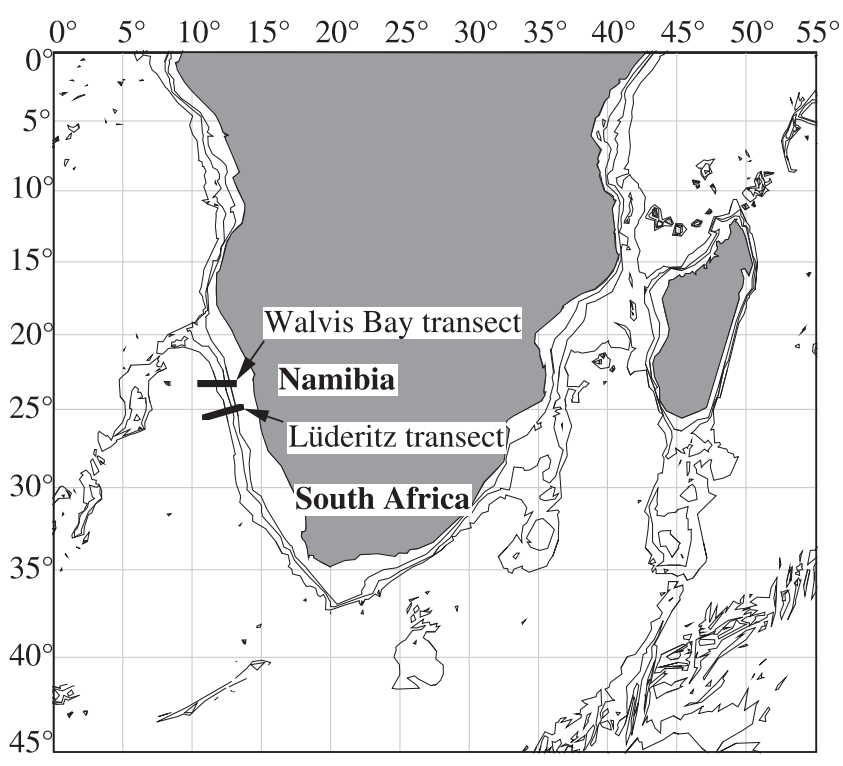

Figure 1. Locations of the two transects along which the cores were raised.

IMAGES II cruise onboard the R/V Marion-Dufresne in 1996, while gravity cores GeoB 1712-4 (998 m water depth) and GeoB92-1710-3 (2987 m water depth) were raised from the Walvis Bay area (Figure 1) during cruise M20/2 of the R/V Meteor in 1992.

[5] The latitudes of the transects correspond to those of the most active and permanent upwelling cells of the Benguela system, namely the Lüderitz and Walvis Bay cells. The sediments are homogeneously bioturbated along the cores implying that oxygen in the bottom water has never been depleted enough to prevent benthic life for significant periods of time. At present, although productivity is strong in surface waters, the water column off the Namibian shelf is not oxygen-depleted enough to promote denitrification [Holmes et al., 1998]. This indicates that intermediate and deep-water masses in this area are well ventilated.

\section{Environmental Setting of the Benguela System and Global Teleconnections}

[6] The circulation of the upper waters in the SE Atlantic along the SW African margin is dominated by the regional wind-driven coastal upwelling activity in the highly productive Benguela Current system [Shannon and Nelson, 1996; Hutchings et al., 1995]. The northerly transport of surface waters in this system is considered to balance salt export from the North Atlantic in the southerly North Atlantic Deep Water (NADW) flow [Berger and Wefer, 1996]. Upstream of the SE Atlantic upper circulation, Southern Indian Ocean water is added into the Benguela Current via the Agulhas Current [Lutjeharms, 1996; Shannon and Nelson, 1996]. Downstream of the Benguela System upper water masses are transported across the equator through the South Equatorial Current via the North Brazil Current connection. Due to the northerly offset of the annual mean position of the present atmospheric intertropical convergence zone (ITCZ) with respect to the equator, the present North Atlantic gain of heat across the equator is significantly positive, whereas it is believed to have been close to zero during the last glacial maximum [Miller and Russel, 1989].

[7] Depending on the activities of northern and southern deep water sources [Diekmann et al., 1996; Duplessy et al., 1996, 1988; Sarnthein et al., 1994] sedimentation on the SE Atlantic margin is also strongly influenced by hydrographic variations in deep and intermediate waters. Paleoclimaterelated changes in the coastal upwelling regime, the eastern boundary current and the heat transport system, as well as the deep-water exchange between hemispheres, are likely to have controlled rates of sedimentation of biogenic carbonates, organic matter and opal on the SW African Margin over the last 3 million years [Bickert and Wefer, 1996; Diester-Haas et al., 1992; Kirst et al., 1999; Lange et al., 1999; Schmiedl and Mackensen, 1997; Summerhayes et al., 1995]. Thus, sedimentation on this margin responds to global-scale processes in the sea.

\section{Results}

[8] We use a suite of proxies to support the interpretation offered in this paper, including isotope measurements in foraminifers, selected major and trace element concentrations, $\%$ opaline $\mathrm{Si}, \% \mathrm{CaCO}_{3}$ and $\% \mathrm{C}_{\text {org }}$ assays and nitrogen isotope measurements made on bulk sediments. Analytical methods used in the study are described in the figure captions.

[9] Age models were established for both Walvis Bay cores [Kirst et al., 1999] using oxygen isotope records of planktonic and benthic foraminifers and AMS radiocarbon dates on the core itself as well as by comparison to the radiocarbon-dated core PG/PC12 [Summerhayes et al., 1995]. Benthic $\delta^{18} \mathrm{O}$ data versus depth and the corresponding isotope stages are reported in Figure 2 for the upper part of the deep core MD96-2086 of the Lüderitz transect. This section of the core spans an interval from $\sim 300,000$ BP to present. Preliminary dating suggests that the oldest sediments recovered in Core MD96-2086 are older than $600 \mathrm{kyr}$.

\subsection{Organic Carbon to Carbonate Relationships}

[10] In the midslope core (MD96-2087) off Lüderitz, organic carbon $\left(\mathrm{C}_{\mathrm{org}}\right)$ contents are never lower than $5 \mathrm{wt} . \%$, and reach concentrations as high as $18 \%$ in some intervals (Figure 3a). Such concentrations are amongst the highest observed in the world in both modern and ancient marine sediments. Even at $2910 \mathrm{~m}$ water depth on the lower slope, most samples analyzed in an additional core (MD96-2098), contain organic carbon concentrations $>3 \%$. At greater water depths, for example, at $3606 \mathrm{~m}$ (Core MD96-2086) $\mathrm{C}_{\text {org }}$ contents higher than $1.5 \%$ are typical (Figures 2 and $3 \mathrm{a}$ ). Simple frequency diagrams of $\mathrm{C}_{\text {org }}$ content in these sediments have been reported by Huc et al. [2001]; these confirm that the deposits host very high organic carbon contents.

[11] Optical examination of palynofacies (E. LallierVerges, unpublished data) reveals that the volume proportion of marine organic particles ranges between 80 and $95 \%$ of the total organic fraction. This large dominance of marine organic matter is confirmed by isotope measurements of organic $\sigma^{13} \mathrm{C}$, which range between -19 and $-20.5 \%$ (P. Bertrand et al., unpublished). Such values correspond to the typical range for modern marine organic matter [Sackett, 1989]. 


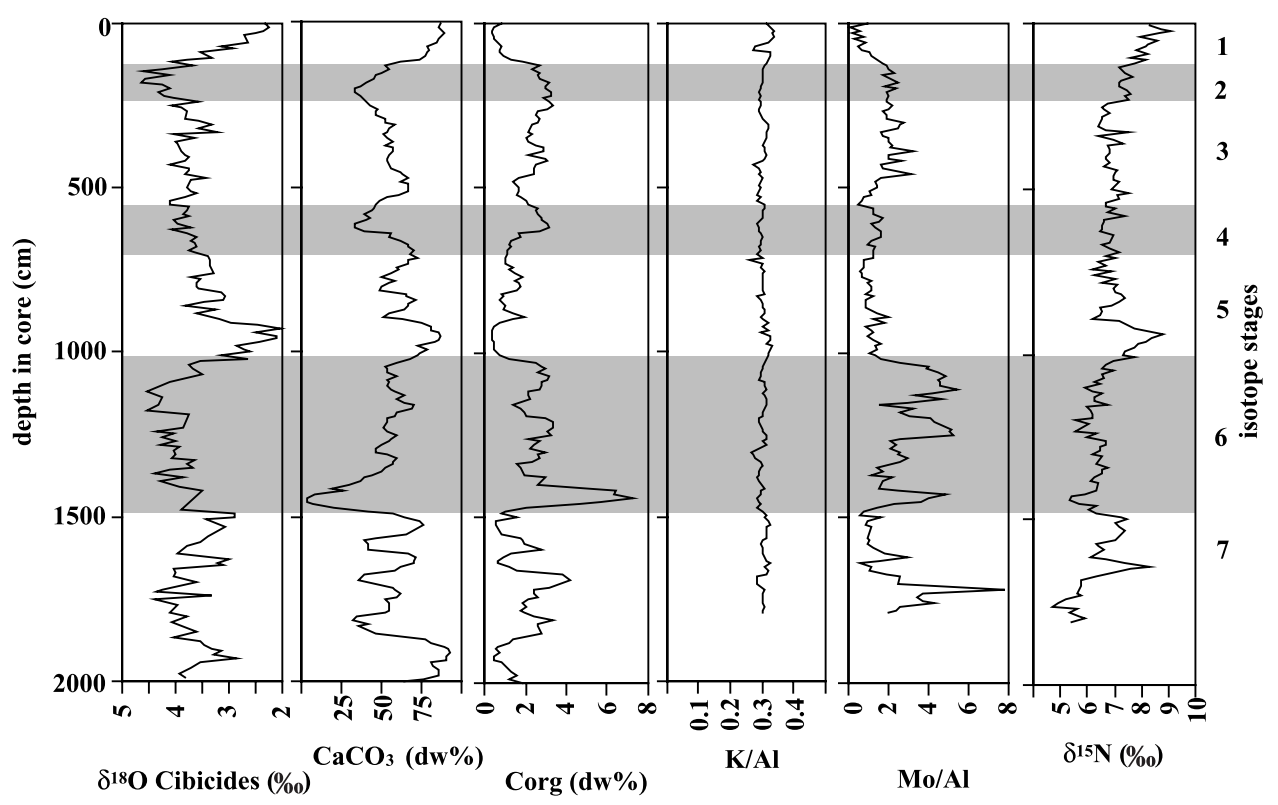

Figure 2. Profiles of benthic foraminifer $\delta^{18} \mathrm{O}, \% \mathrm{CaCO}_{3}, \% \mathrm{C}_{\mathrm{org}}, \mathrm{K} / \mathrm{Al}, \mathrm{Mo} / \mathrm{Al}$, and $\delta^{15} \mathrm{~N}$ versus depth in the deep core MD96-2086. Cold episodes (isotope stages 2, 4, and 6) correspond to the shaded areas. Methods are given in the results section $\left(\delta^{18} \mathrm{O}\right)$ and in the captions to Figures $3-7$. Note the relative constancy of the $\mathrm{K} / \mathrm{Al}$ ratio with depth.

[12] Common features in the statistical relationships between organic carbon and carbonate contents (Figures $3 \mathrm{a}$ and $3 \mathrm{~b}$ ) are observed for cores of equivalent bathymetric position, indicating that water depth and/or distance from the upwelling area are amongst the major controls on the carbonate/organic carbon ratio in the sediments of this region. Within a given core, however, this ratio is mainly related to climate changes. Based on the age models of the cores, we observe that carbonate depletion and related organic enrichment correspond statistically to warm to cold transitions and vice versa. In any case, major changes over the lengths of the intervals sampled in the cores occur as quasi-linear trends on a $\mathrm{CaCO}_{3}$ versus TOC plot, which converge toward or diverge from the $100 \% \mathrm{CaCO}_{3}$ pole. The intercept of the linear relationship at $100 \% \mathrm{CaCO}_{3}$ means that the buried (fossilized) flux of carbonate is the major control for the sediment composition. The buried $\mathrm{CaCO}_{3}$ flux is the net result of the sedimentation and dissolution fluxes for $\mathrm{CaCO}_{3}$. Any modification of the other buried fluxes (organic and/or detrital) would result unavoidably in deviations toward or from the two other poles of the diagram $\left(100 \% \mathrm{C}_{\text {org }}\right.$ and $\left.0 \% \mathrm{C}_{\text {org }}-0 \% \mathrm{CaCO}_{3}\right)$. The upper slope sediments slightly differ from the $\mathrm{CaCO}_{3} / \mathrm{Corg}$ trends seen at the deeper sites (Figure 3), especially within the intervals that host the highest organic carbon concentrations. As discussed below, this may be due to enhanced preservation of metabolizable organic carbon.

\subsection{Major Element Relationships}

[13] The same trends with respect to calcium carbonate concentrations appear for concentrations of major or minor elements such as K, Al, Fe, Ti, and Si (Figure 4). As noted above, this means that variability in the carbonate accumulation rate, either through sedimentary input and/or dissolution, is the main factor that influences the bulk sediment composition in this region. $\mathrm{K} / \mathrm{Al}, \mathrm{Si} / \mathrm{Al}, \mathrm{Ti} / \mathrm{Al}$, and $\mathrm{Fe} / \mathrm{Al}$ weight ratios are generally invariant irrespective of the $\mathrm{CaCO}_{3}$ content (see, for example, the $\mathrm{K} / \mathrm{Al}$ versus depth profile in Figure 2 and the quasi-linear relationships in Figure 4).

[14] Although the remainder of the results and discussion below will focus only on the conditions for organic matter enrichment at pelagic depths, i.e., at $3606 \mathrm{~m}$, similar comments and conclusions apply to the shallower sites where the sedimentary organic matter content is even higher. We focus here on the lower slope because investigating oil source potential of settings of this type $(>2000 \mathrm{~m}$ water depth) is of high interest for possible future offshore oil exploration, while drilling on upper continental slopes is already operational.

[15] Organic carbon and $\mathrm{Si}$ in the deposits at $3606 \mathrm{~m}$ water depth also exhibit conservative behavior with respect to carbonate as indicated by the good linear relationships between $\mathrm{C}_{\text {org }}$ and $\mathrm{CaCO}_{3}$ and $\mathrm{Si}$ and $\mathrm{CaCO}_{3}$ shown in Figure 5. The relationship for $\mathrm{Si}$ is similar to those of the detrital elements (Figure 4) implying that preserved Si on the deeper slope mainly reflects the presence of detrital silicates and aluminosilicates, and that only a minor or trace proportion occurs as biogenic opal. This is supported by opal measurements made on Core MD96-2086, which ranged from less than $0.2 \mathrm{wt} \%$ (as $\mathrm{Si}$ ) in samples with high total Si contents to around 0.35 wt.\% (as $\mathrm{Si}$ ) in samples with low total Si concentrations [Bertrand et al., 2002].

\subsection{Molybdenum and Benthic Redox Conditions}

[16] The concentration of molybdenum in sediments is known to be sensitive to redox conditions because Mo is fixed in deposits only where anoxic conditions exist [Crusius et al., 1996] and active sulfate reduction is occurring [Helz et al., 1996]. In our case where continuous bioturbation has 

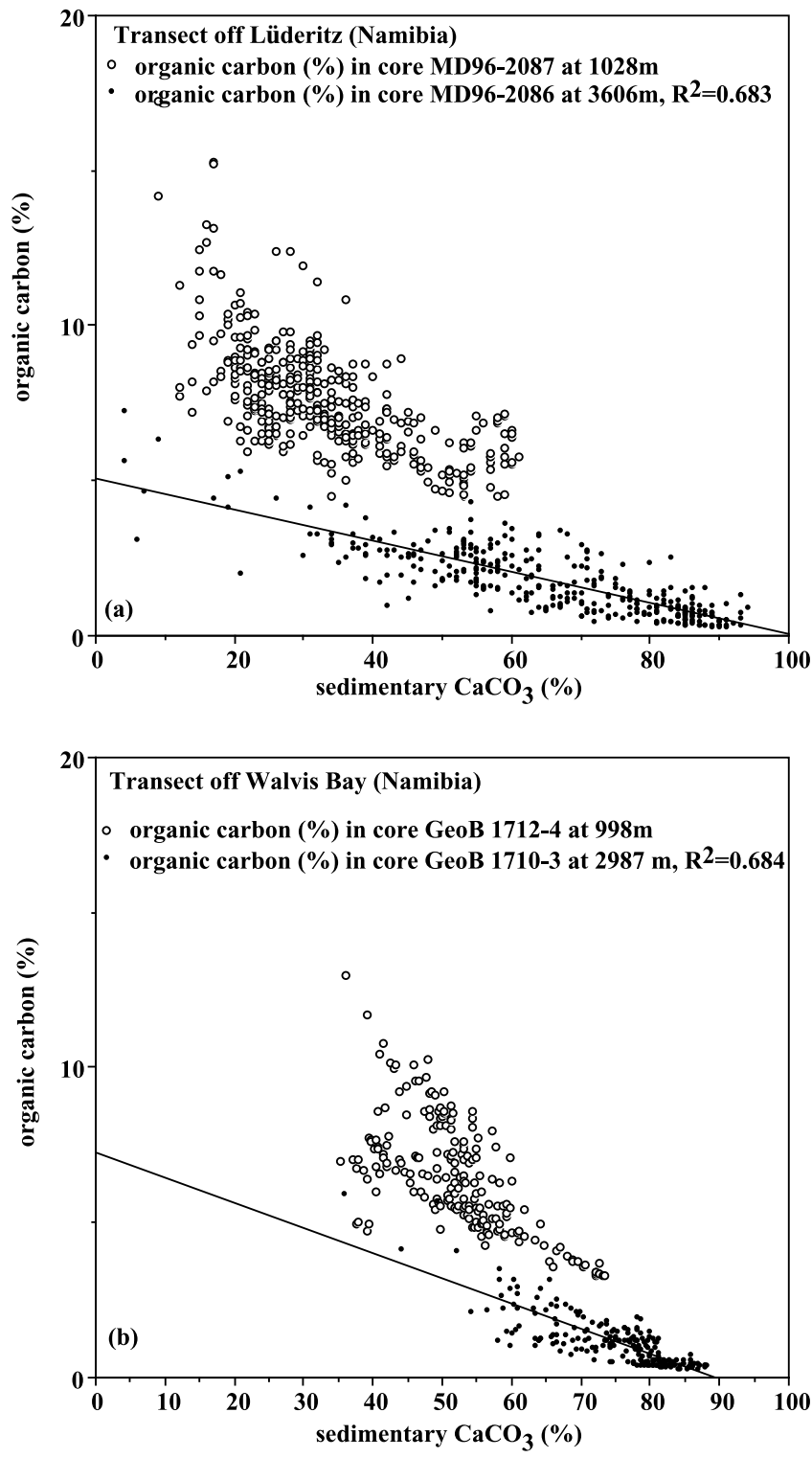

Figure 3. Organic carbon versus carbonate contents for cores (a) of the Lüderitz transect and (b) of the Walvis Bay transect. Regression lines are shown only for the deep cores. Organic carbon contents were measured by a LECO C,S analyzer after removing carbonates, while carbonate contents were measured by the classical coulometric method using hydrochloric acid. Relative uncertainty on both measurements is better than $5 \%$. Regression lines converge toward the $100 \% \mathrm{CaCO}_{3}$ pole.

occurred, we infer that the sediment-water interface has never been fully depleted in oxygen, and that redox variations occur only within the sediments as vertical movements of the redox front. When the redox front is shallow, downward diffusion of Mo from seawater is more efficient and more Mo is precipitated in the deposits just below the oxicanoxic boundary where sulfate reduction is occurring. Figure 5 shows that the Mo to $\mathrm{CaCO}_{3}$ ratio is significantly higher for carbonate contents $<60 \%$, implying that the redox front within the sediments was shallower during cold episodes when net relative carbonate accumulation was reduced. The highest Mo contents ( $>20 \mathrm{ppm})$ are found in intervals where visual indices of carbonate dissolution are most expressed and where the lowest carbonate contents occur.

\subsection{Hydrogen and Oxygen Indices}

[17] The degree of preservation of the organic matter can, at least to first order, be estimated by Rock-Eval pyrolysis, especially via Hydrogen (HI) and Oxygen indices (OI), the values of which correlate with the $\mathrm{H} / \mathrm{C}$ and $\mathrm{O} / \mathrm{C}$ atomic ratios of the mineral-free organic matter, respectively. The OI expressed in $\mathrm{mg} \mathrm{CO}_{2} \cdot \mathrm{g}^{-1} \mathrm{TOC}$ is calculated from the TOC and from the $\mathrm{CO}_{2}$ evolved during the beginning of the programmed pyrolysis of the samples under an inert atmosphere, up to $390^{\circ} \mathrm{C}$ [Espitalié et al., 1985a, 1985b]. Most or almost all of the $\mathrm{CO}_{2}$ from the organic matter is released before this temperature is reached; beyond this limit, $\mathrm{CO}_{2}$ is considered to be released by the thermal decomposition of carbonates. However, in the present case, as in most carbonate-rich recent sediments, the decomposition of carbonates begins below $390^{\circ} \mathrm{C}$ and this can make unreliable OI estimates in carbonate-rich, organic carbon-poor sediments. In Figure 6a we plot the amounts of $\mathrm{CO}_{2}$ released at $\mathrm{T}<$ $390^{\circ} \mathrm{C}$ (S3) against TOC. This shows that samples that contain $<2 \%$ TOC can be considered as having an approximately constant OI of $\sim 220 \mathrm{mg} \mathrm{CO} 2 \cdot \mathrm{g}^{-1} \mathrm{TOC}$, given by the slope of the regression line (Figure 6a). Thus, the organic matter composition does not appear to vary irrespective of the organic carbon concentration where that concentration is less than about 2 wt.\%. The intercept of the regression line with the ordinate in Figure $6 \mathrm{a}$ is assumed to represent a constant amount of $\mathrm{CO}_{2}$ issued from carbonate decomposition. A slightly lower OI is indicated for samples with $>2$ wt. $\% \mathrm{C}_{\text {org }}$ but the scatter in these data precludes drawing a firm conclusion.

[18] A stronger confirmation of the general constancy of composition of the organic matter irrespective of concentration is provided by $\mathrm{HI}$ estimates (Figure 6b). These fall between 340 and $420 \mathrm{mg} \mathrm{HC} \mathrm{g}^{-1}$ TOC, with the exception of five samples taken between 1482 and $1522 \mathrm{~cm}$ depth in the core that have noticeably lower HI values, i.e., 200 to $260 \mathrm{mg} \mathrm{HC} \cdot \mathrm{g}^{-1}$ TOC. The absence of any significant decline in HI with decreasing TOC is at variance with previous work where lower $\mathrm{HI}$ values at low $\mathrm{C}_{\text {org }}$ concentrations have been interpreted as reflecting increasing alteration of organic matter with a decreasing sedimentary input flux. This in turn is thought to reflect decreasing primary production in overlying surface waters [e.g., Ramanampisoa and Disnar, 1994]. Moreover, the absence of significant variations in $\mathrm{HI}$ values in this study implies that there is no retention of hydrocarbon compounds by the mineral matrix and especially by reactive clays during the programmed pyrolysis [Espitalié et al., 1985b; Langford and BlancValleron, 1990; Ganeshram et al., 1999]. This apparent absence of interactions between organic matter and clays implies that such minerals very probably played no role in the preservation of the organic matter through the so-called "absorptive preservation pathway."

\subsection{Nitrogen Isotope Ratios and Past Trophic Conditions}

[19] The isotopic fractionation of sedimentary organic nitrogen in coastal upwelling areas such as that off Namibia 


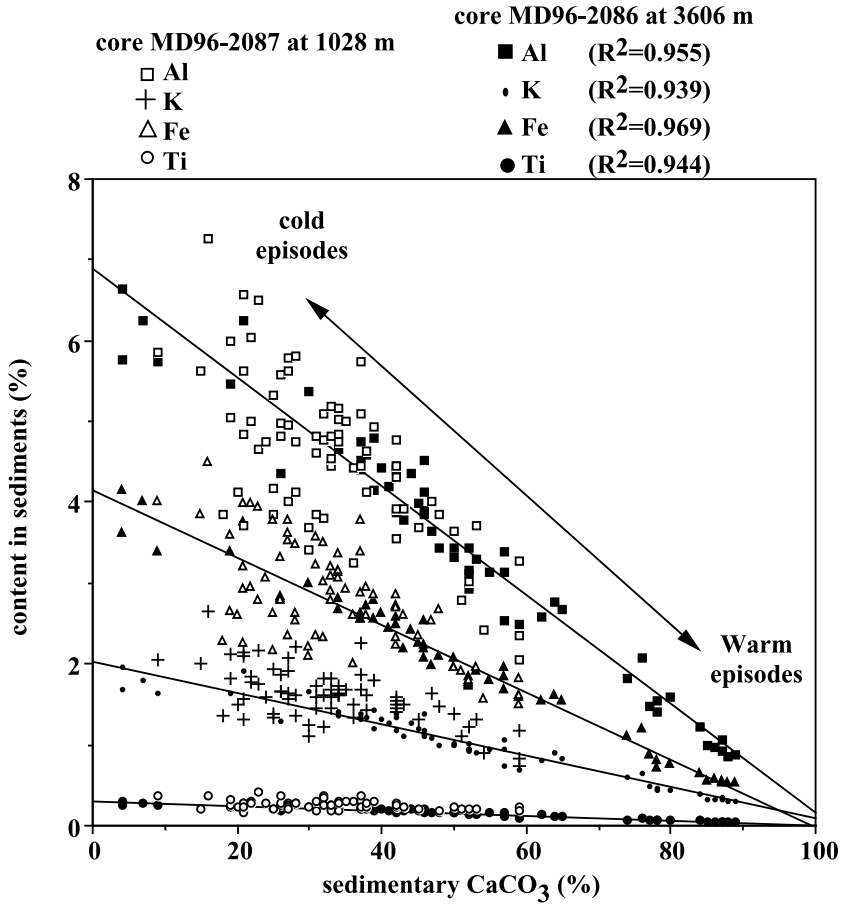

Figure 4. $\mathrm{Al}, \mathrm{K}, \mathrm{Fe}$, and $\mathrm{Ti}$ versus carbonate contents for the Lüderitz cores. Regression lines are shown only for the data from the deep core at $3606 \mathrm{~m}$. The major element contents were measured by X-ray fluorescence, and the values were corrected for dilution and contribution of residual sea salt. Intersections of regression lines with the vertical axis give the mean concentrations of these elements on a carbonate-free basis. The regression lines converge toward the $100 \% \mathrm{CaCO}_{3}$ pole.

may be mostly influenced by two main processes: (1) the relative utilization of nitrate in surface water [Holmes et al., 1998]; and (2) by denitrification in oxygen-depleted water columns [Altabet et al., 1995; Ganeshram et al., 1995]. Primary producers preferentially take up light nitrogen $\left({ }^{14} \mathrm{~N}\right)$ from dissolved nitrate during photosynthetic production of organic matter. Therefore, if the supply of light nitrate-hosted nitrogen to the euphotic zone by upwelling subsurface water exceeds demand by the phytoplankton, the exported particulate organic nitrogen will be isotopically light. The converse is true where demand exceeds supply: in this case, nitrate remaining in surface waters is progressively enriched in the heavy isotope $\left({ }^{15} \mathrm{~N}\right)$. Thus, particulate organic nitrogen exported from the euphotic zone will become progressively "heavy" as waters that well up at one location are gradually advected away from the upwelling point [Farrell et al., 1995]. We note that the $\delta^{15} \mathrm{~N}$ signal that results from relative nitrate utilization can be modified by the shallow recycling of particulate organic nitrogen into nitrate [Bertrand et al., 2000]. Such an effect is generally observed in cores sampled from the upper slopes, however [Bertrand et al., 2000], and we assume here that the impact of such an effect on sediments at $3.6 \mathrm{~km}$ water depth can be neglected.

[20] Denitrification is an anaerobic bacterial process that transforms nitrate into gaseous products such as $\mathrm{N}_{2} \mathrm{O}$ and $\mathrm{N}_{2}$ that are enriched in light nitrogen and are removed from the ocean to the atmosphere. Oxygen minimum zones in which oxygen concentrations fall to near zero are the principal sites of water column denitrification in the modern ocean. The loss from the upper intermediate water column of the isotopically light products produced by denitrification yields residual dissolved nitrate that is enriched in ${ }^{15} \mathrm{~N}$. The subsequent upwelling and assimilation of the "heavy" nitrate by phytoplankton supports the export of isotopically enriched particulate organic matter in oxygen minimum regions [e.g., Altabet et al., 1995; Ganeshram et al., 1995].

[21] Figures 2 and 7show the relationship between the measured isotopic composition of the sedimentary organic nitrogen and the carbonate content. Sedimentary nitrogen became isotopically heavier when global climate shifted from cold to warm episodes, for example across the transitions from stages 6.1 to 5.5 and 2 to 1 . Conversely, sedimentary nitrogen became lighter as conditions shifted from warm to cold, for example across the transitions between stages 7.1 and 6.6 , or 5.5 and 5.4. As argued below, these variations are consistent with changes in relative nutrient utilization and not denitrification.

\section{Discussion}

[22] Constant major element ratios downcore (Figures 2 and 4) strongly support the hypothesis that the provenance and mineralogy of the terrestrial detrital fraction, as well as any sorting effects due to hydrodynamic influences, have

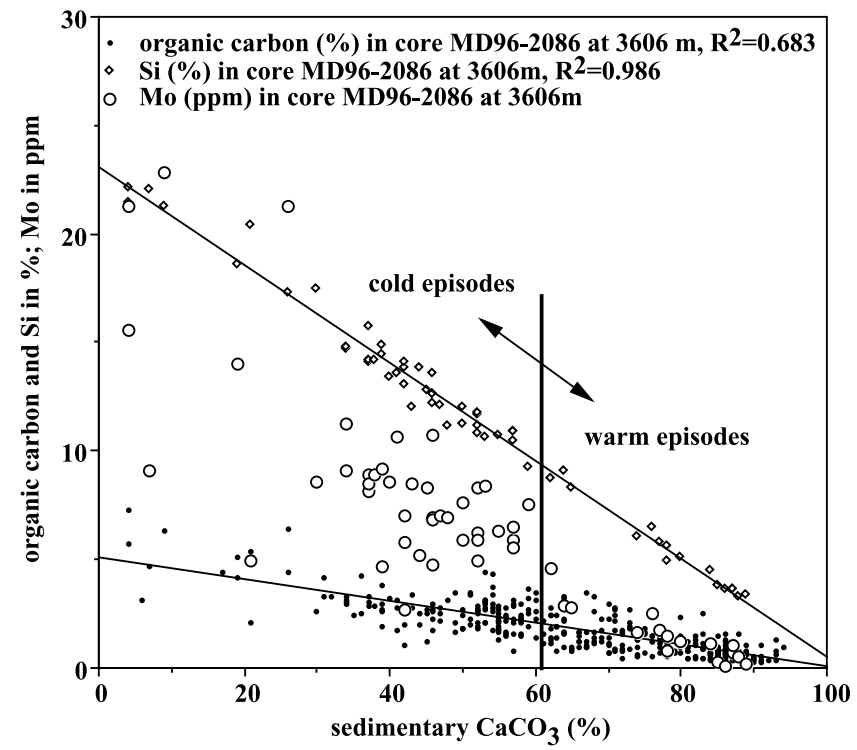

Figure 5. $\mathrm{Si}$, organic carbon, and Mo contents versus carbonate contents for core MD96-2086. Si contents were measured by XRF as for the other major elements (see caption for Figure 4). Mo contents were measured by both XRF and ICP-MS, showing good agreement between the two sets of data. Only XRF Mo data are presented in this figure, as well as in Figure 2. Si and organic carbon contents are linearly related to carbonate content with regression lines converging toward the $100 \% \mathrm{CaCO}_{3}$ pole, while $\mathrm{Mo}$ contents show a deviation for carbonate contents lower than $60 \%$. 
been essentially constant during the late Quaternary off both Luderitz and Walvis Bays. Any significant change in the sources, fluxes, or hydrodynamic redistribution of detrital minerals should have resulted in visible changes in the relative distributions of the major elements. Furthermore, were the fluxes of detrital minerals to have changed independently through time, the relationships shown in Figure 4 would be less linear. That obvious nonlinearities are not present simplifies our interpretation.

[23] Given that the carbonates are biogenic, comprising almost entirely foraminifers and coccoliths, variations in the $\mathrm{CaCO}_{3}$ content downcore must reflect the interaction of productivity changes, and diagenesis. Variations induced by changes in current scour (winnowing) are ruled out by the constancy of the major element ratio distributions. The quasi-linear relationship between organic carbon and $\% \mathrm{CaCO}_{3}$ observed in sediments deposited on the lower slope (core MD96-2086, Figures 3 and 5) must therefore be attributable to the collective influences of production and
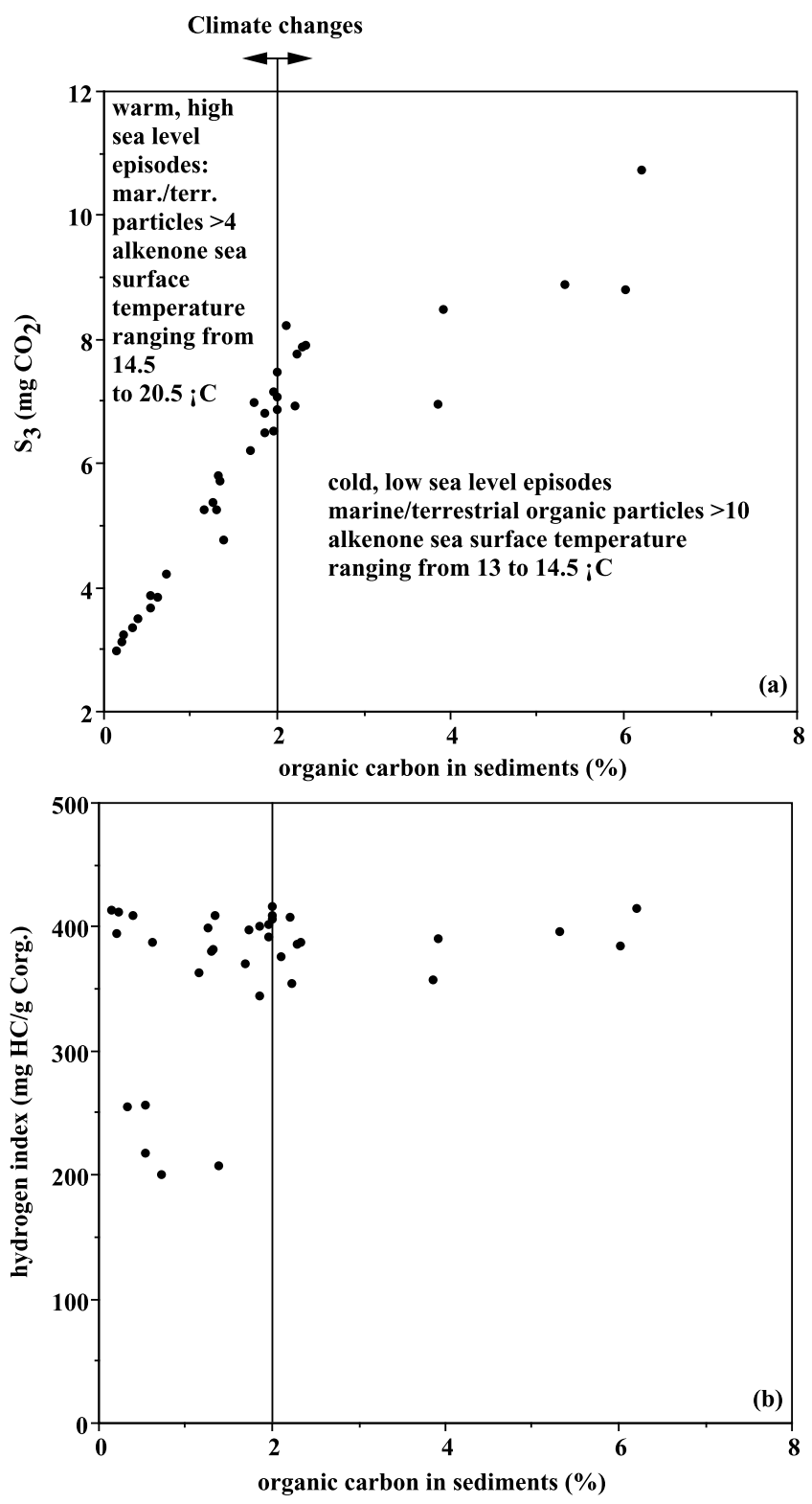

diagenesis. The discussion below offers a simple explanation for this important interaction.

[24] In the most organic-rich intervals, carbonate dissolution is clearly evidenced by very poor preservation of foraminifer shells. In these intervals, only thin broken fragments of tests occur. Such dissolution is favored by metabolic addition of $\mathrm{CO}_{2}$ to shallow pore waters due to oxic degradation of organic matter [Hales et al., 1994]. This induces a shift of the carbonate equilibrium $2 \mathrm{HCO}_{3}{ }^{-} \Longleftrightarrow$ $\mathrm{CO}_{2}+\mathrm{CO}_{3}{ }^{=}+\mathrm{H}_{2} \mathrm{O}$ in the interstitial water toward the bicarbonate pole so that dissolved $\mathrm{CO}_{3}{ }^{=}$in the interstitial water is depleted, leading to dissolution of $\mathrm{CaCO}_{3}$. The correspondence downcore between visual observations of increased foraminifer fragmentation and higher measured $\mathrm{C}_{\text {org }}$ concentrations (Figure 2) implies that such episodes of aerobic decay of organic matter indeed resulted in periods of enhanced carbonate dissolution. The intervening intervals of better preservation and generally higher $\mathrm{CaCO}_{3}$ content could reflect either: (1) diminished production of metabolic $\mathrm{CO}_{2}$ at times of lower benthic flux of settling organic matter; (2) increased rain rate of $\mathrm{CaCO}_{3}$ relative to $\mathrm{C}_{\text {org }}$; (3) an increase in the alkalinity of the water mass that bathes this portion of the slope; or (4) enhanced production of alkalinity consequent upon sulfate reduction, which is known to encourage carbonate preservation [Berger and Soutar, 1970]. Compelling evidence that the latter option did not make a contribution is provided by the downcore $\mathrm{Mo} / \mathrm{Al}$ profile. Periods of enhanced sulfate reduction are marked by the relative Mo enrichments (Figure 2); these are associated with times of increased fragmentation, not preservation, of foraminifers, and lower $\mathrm{CaCO}_{3}$ concentrations as well as increased $\mathrm{C}_{\text {org }}$ contents. The implication is that during glacial stages, increased export of organic matter

Figure 6. (opposite) S3 and Hydrogen Index (HI) versus organic carbon contents of sediments of core MD 96-2086. These parameters were measured by the Rock-Eval pyrolysis procedure [Espitalié et al., 1985a, 1985b]. S3 expresses the amount of $\mathrm{CO}_{2}$ in $\mathrm{mg}$ released during stepwise pyrolysis of the organic matter up to a temperature of $390^{\circ} \mathrm{C}$ (heating under an inert carrier gas flow). Below $390^{\circ} \mathrm{C}, \mathrm{S} 3$ is not significantly affected by the thermal decomposition of carbonates. The Hydrogen Index is the quantity of potential hydrocarbons in $\mathrm{mg}$ per gram of organic $\mathrm{C}$ that are released from the organic matter during pyrolysis up to $600^{\circ} \mathrm{C}$. RockEval pyrolysis was applied to a restricted set of samples that represented two major climatic transitions: the last deglaciation and the onset of glaciation between isotope stages 7 and 6. The vertical line at $2 \% \mathrm{C}_{\text {org }}$ corresponds to the limit observed on Figure 4 at $60 \%$ carbonate content. In this figure the $\% \mathrm{C}_{\text {org }}$ is the value measured by the Rock-Eval pyrolysis [Espitalié et al., 1985a, 1985b]. Organic carbon concentration values from Rock-Eval are very close to those obtained by the LECO analyzer after decarbonation. The relative difference between values from the two methods is always less than $10 \%$. The marine to terrestrial particle ratios mentioned at the top of the plot were determined by counting particles in organic matter isolates obtained for palynofacies preparation. Alkenone SST estimates (top of plot) are based on unpublished $\mathrm{U}_{\mathrm{k}}^{37}$ measurements made at Bordeaux by J. Villanueva. 


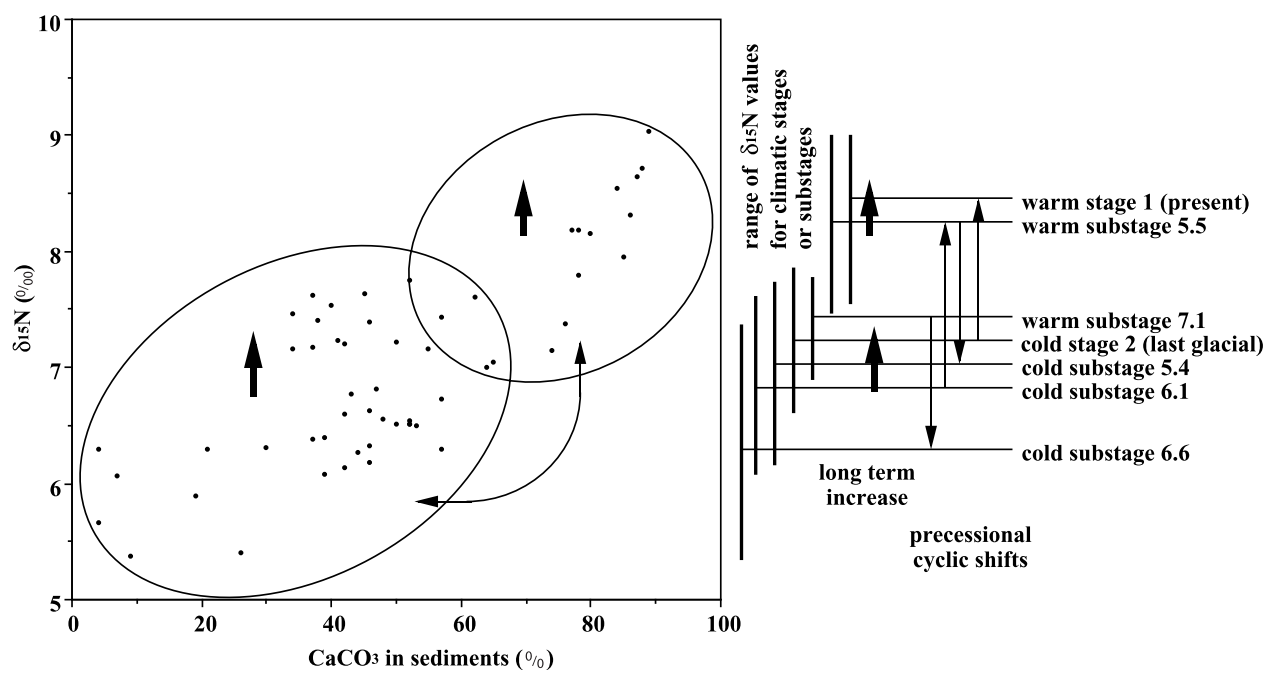

Figure 7. Isotopic composition of sedimentary nitrogen versus carbonate contents. Here $\delta^{15} \mathrm{~N}=$ $\left[\left({ }^{15} \mathrm{~N} /{ }^{14} \mathrm{~N}\right)\right.$ sample $/\left({ }^{15} \mathrm{~N} /{ }^{14} \mathrm{~N}\right)$ standard -1$] \times 1000$. Vertical segments on the right side of the diagram represent the ranges of $\delta^{15} \mathrm{~N}$ values for climatic stages or substages. Clusters represent cold $\left(\mathrm{CaCO}_{3}<\right.$ $60 \%)$ and warm $\left(\mathrm{CaCO}_{3}>60 \%\right)$ episodes. Bold arrows represent a long-term increase in $\delta^{15} \mathrm{~N}$ values, as observed in the $\delta^{15} \mathrm{~N}$ profile of Figure 2.

from the surface waters supported enhanced production of metabolic $\mathrm{CO}_{2}$ through aerobic decay, more vigorous dissolution of foraminifer shells, a shallower redox boundary, and increased subsurface sulfate reduction, even at $3600 \mathrm{~m}$ water depth. The upper part of the sediment column remained oxic during such periods, as confirmed by the continuously bioturbated sedimentary facies downcore.

[25] The first two options above, diminished $\mathrm{CO}_{2}$ production or increased relative carbonate rain, go hand in hand. Since the HI data rule out downcore compositional variations in the buried organic fraction (see below), it is unlikely that changes in the degree to which the organic matter was metabolizable controlled $\mathrm{CO}_{2}$ production and carbonate dissolution rates in the deposits. Rather, changes in the settling flux of organic carbon, relative to carbonate, would appear to have provided the first-order control. Time control on the core is very limited, but sedimentation rates can be crudely estimated by ascribing age picks to the stage boundaries shown in Figure 2. This yields linear sedimentation rates of $9,9,6.5$, and $8.5 \mathrm{~cm} \mathrm{kyr}^{-1}$ for stages 3 through 6 , respectively. Thus, changes in the organic carbon and carbonate accumulation rates primarily reflect the $\% \mathrm{C}_{\text {org }}$ and $\% \mathrm{CaCO}_{3}$ profiles in the bulk sediments and not variations in linear sedimentation. Where the $\mathrm{C}_{\text {org }}$ burial flux (i.e., $\% \mathrm{C}_{\text {org }}$ ) is low, the carbonate burial flux ( $\mathrm{read},{ }_{0} \mathrm{CaCO}_{3}$ ) is high and more importantly, preservation of foraminifers is enhanced. These observations in concert suggest that times of reduced settling flux of $\mathrm{C}_{\text {org }}$ led to decreased dissolution of $\mathrm{CaCO}_{3}$. Finally, temporal changes in the chemical character of the bottom water due to hydrographic variability could also have influenced carbonate dissolution at this site. This possibility is discussed further below.

[26] Despite the perennial oxidizing conditions at the sediment surface and the considerable water depth (3.6 $\mathrm{km})$ at the site, high concentrations of organic matter are common in core MD96-2086. The preservation of the residual organic fraction could have resulted from the "adsorptive preservation" of labile organic matter on mineral surfaces [Keil et al., 1994]. However, this mechanism is controversial [Ransom et al., 1997] and is not in good agreement with our own palynofacies observations. These show that large numbers of recognizable organic matter particles are present in the deposits. Moreover, adsorptive preservation is not coherent with Rock-Eval results, which show an apparent absence of interactions between organic matter and clays, as discussed earlier. Finally, the constant hydrogen index around $400 \mathrm{mg} \mathrm{HC} / \mathrm{g} \mathrm{C}_{\mathrm{org}}$ whatever the $\mathrm{C}_{\text {org }}$ content in sediments (Figure 6, except for five samples) indicates that the degree of preservation of the residual organic matter is essentially constant. We therefore assume that most of the preserved organic matter is composed of resistant marine organic matter (biopolymers) that has been more or less selectively preserved through the more classical "selective preservation pathway" [Derenne et al., 1990].

[27] Previous work [Holmes et al., 1998] has shown that sedimentary $\sigma^{15} \mathrm{~N}$ in this region is much more influenced by relative nitrate utilization than by denitrification. Sedimentary nitrogen becomes isotopically heavier at sites located progressively offshore, or farther from the upwelling zones. Although water column denitrification is not observed in the region today, we cannot exclude the possibility that it was present in the past and that this could have affected the ${ }^{15} \mathrm{~N}$ record. However, denitrification would have produced higher $\delta^{15} \mathrm{~N}$ values and Figure 7 shows that lower values are observed at all times prior to the present interglacial (stage 1), excepting stage 5e and midstage 7 . Therefore we assume that relative nitrate utilization has been the major influence on the isotope composition of sedimentary nitrogen in this region for at least the past 340,000 years. In an upwelling system such as the Benguela, the euphotic layer is mainly fertilized in the nearshore region by nitrate advected vertically from below. Ekman transport offshore, via eddies and filaments, and progressive utilization of nutrients, leads to a gradual trophic shift from extremely eutrophic (i.e., a 
large stock of nutrients with respect to biomass) to less eutrophic through mesotrophic to oligotrophic (few nutrients available with respect to biomass) conditions. The farther the point of primary production from the upwelling zone, the more nitrate should be utilized. Therefore, we infer from the $\delta^{15} \mathrm{~N}$ profile (Figure 2) that the sedimentary organic matter deposited at $3606 \mathrm{~m}$ was on average produced under less eutrophic conditions farther from the upwelling zone during warm episodes than during cold periods. Because the core location is fixed, this must primarily reflect spatial oscillations of both the point of upwelling and the trophic intensity of the surface waters that overlie the core site.

[28] Such movements may be due, at least in part, to sea level variations. The fact that the largest variations in $\delta^{15} \mathrm{~N}$ occur during climatic transitions associated with the largest changes in ice volume (i.e., stages 7.1 to $6.6 ; 6.1$ to $5.5 ; 2$ to 1 ; Figure 2) lends support to this hypothesis. We note that this hypothesis can also explain why more carbonate was dissolved and more organic matter accumulated during cold episodes. Offshore movement of eutrophic highly productive surface waters during low sea stands (cold intervals) would contribute to the export and accumulation of a greater proportion of organic matter at the site of Core MD96-2086. This is because in a eutrophic regime, the ratio of the exported to the primary production (the $f$ ratio) is generally higher [Eppley and Peterson, 1979]. Absence of biological steady state between primary and secondary producers leads to enhanced export of detrital phytoplankton as aggregates and large fecal pellets and this favors rapid transfer to the seafloor of both resistant and metabolizable organic matter and higher rates of organic matter sedimentation. Under the deep, well-ventilated bottom waters on the lower slope off Lüderitz, oxidation of the resistant organic matter is minimized by rapid burial, while a lower proportion of metabolizable organic matter is degraded in the water column in favor of a greater proportion being oxidized aerobically within the benthic layer, i.e., at or near the sediment surface. This depletion favors carbonate dissolution, which is what we observe for the cold stages of the core, both visually in terms of foraminifer fragmentation and in the $\% \mathrm{CaCO}_{3}$ profile. Conversely, during high sea stands when the eutrophic surface waters move inshore, a greater proportion of organic matter is recycled in the more nutrient-depleted waters of the upper ocean above the core site, and proportionately less organic matter is transferred quickly to the seafloor. Thus, less metabolizable organic matter reaches the site. The associated reduced rate of production of $\mathrm{CO}_{2}$ favors carbonate preservation. Finally, we note that the higher content of carbonate in sediments deposited during the warm episodes may also be partly due to the fact that less eutrophic conditions favor carbonate producers such as coccoliths and calcareous zooplankton. Siliceous producers such as diatoms are known to develop preferentially in strongly eutrophic settings [Peinert et al., 1989].

\section{Paleoceanographic Implications}

[29] This area of the Southern Atlantic Ocean has been alternately bathed by North Atlantic Deep Water (NADW) and by Atlantic Antarctic Bottom Water (AABW) [Diekmann et al., 1996; Duplessy et al., 1996, 1988; Sarnthein et al., 1994]. AABW is thought to be more corrosive for carbonates off southwest Africa because it accumulates $\mathrm{CO}_{2}$ from the degradation of organic matter as it flows north under the intensely productive polar-subtropical front. At the latitude of core MD96-2086, the added $\mathrm{CO}_{2}$ has not yet been fully buffered by dissolution of sedimentary carbonates. Thus, carbonates will tend to dissolve in sediments in contact with this water mass as it flows north.

[30] Previous studies of benthic-foram carbon isotope records from the Cape Basin have suggested that NADW and $\mathrm{AABW}$ are alternately present, with $\mathrm{AABW}$ being dominant during glacial episodes [Bickert and Wefer, 1999; Oppo and Fairbanks, 1990; Oppo et al., 1990]. Therefore the presence of southern bottom waters at the depth of the deep sites probably enhanced carbonate dissolution during glacial stages,. It is important to note that the importation of corrosive bottom water during glacial intervals could not have been the only control on the extent of calcite burial in these sediments. The metabolizable organic carbon settling flux must have increased concurrently, as argued above on the basis of the Mo/Al and $\delta^{15} \mathrm{~N}$ data.

[31] Finally, we come back to the observation that, on the lower slope, $\mathrm{C}_{\text {org }}$ is linearly correlated to $\mathrm{CaCO}_{3}$ (Figures 3 and 5). We conclude that this can be only explained by a combination of conditions; these are illustrated by a simple conceptual model built on four observations. First, the constancy of the HI data and the constancy of major element ratios imply little compositional variation in the noncarbonate refractory fraction, whatever the climate, cold or warm. Second, the flux of resistant organic matter exported from the euphotic layer and the terrestrial detrital fluxes must have been transferred or advected to the site with the same relative efficiency during both warm and cold episodes as shown by the generally similar relationships between major element: $\mathrm{CaCO}_{3}$ ratios (Figure 4) and $\mathrm{C}_{\text {org }}$ : $\mathrm{CaCO}_{3}$ ratios (Figure 3). Furthermore such fluxes must have been relatively constant; otherwise the quasi-linear relationships shown in the $\mathrm{x}-\mathrm{y}$ plots would break down as argued earlier. Third, because the waters near the coast are the most productive due to more eutrophic conditions, and because the organic matter is almost entirely of marine origin (as shown by $\delta^{13} \mathrm{C}_{\mathrm{org}}$ data and palynofacies observations) we can assume that most of the resistant organic matter flux originated from the eutrophic zone, and that this has always been located inshore of the site. Fourth, changes in metabolizable organic matter flux to the sediment must have modified bottom conditions and the dissolution of carbonate and hence modulated the flux of fossilized carbonate. The evidence for this lies in the form of increased fragmentation of foraminifers at times of high $\mathrm{C}_{\text {org }}$ concentration in the deposits. Because $\mathrm{C}_{\text {org }}$ concentrations downcore vary by a factor of up to five while the sedimentation rate, albeit crudely estimated, varies by only $\pm 50 \%$, high $\% \mathrm{C}_{\text {org }}$ contents imply high $\mathrm{C}_{\text {org }}$ settling flux.

[32] This conceptual view can be summarized and its credibility tested using a simple nonparameterized numerical model in which initial fluxes vary from eutrophic to less eutrophic conditions (Figure 8a). On the basis of the observations above, we assume that relative fluxes of conservative detrital minerals and of resistant organic matter to the site of core MD96-2086 did not change very much between warm and cold episodes, and we include them as 


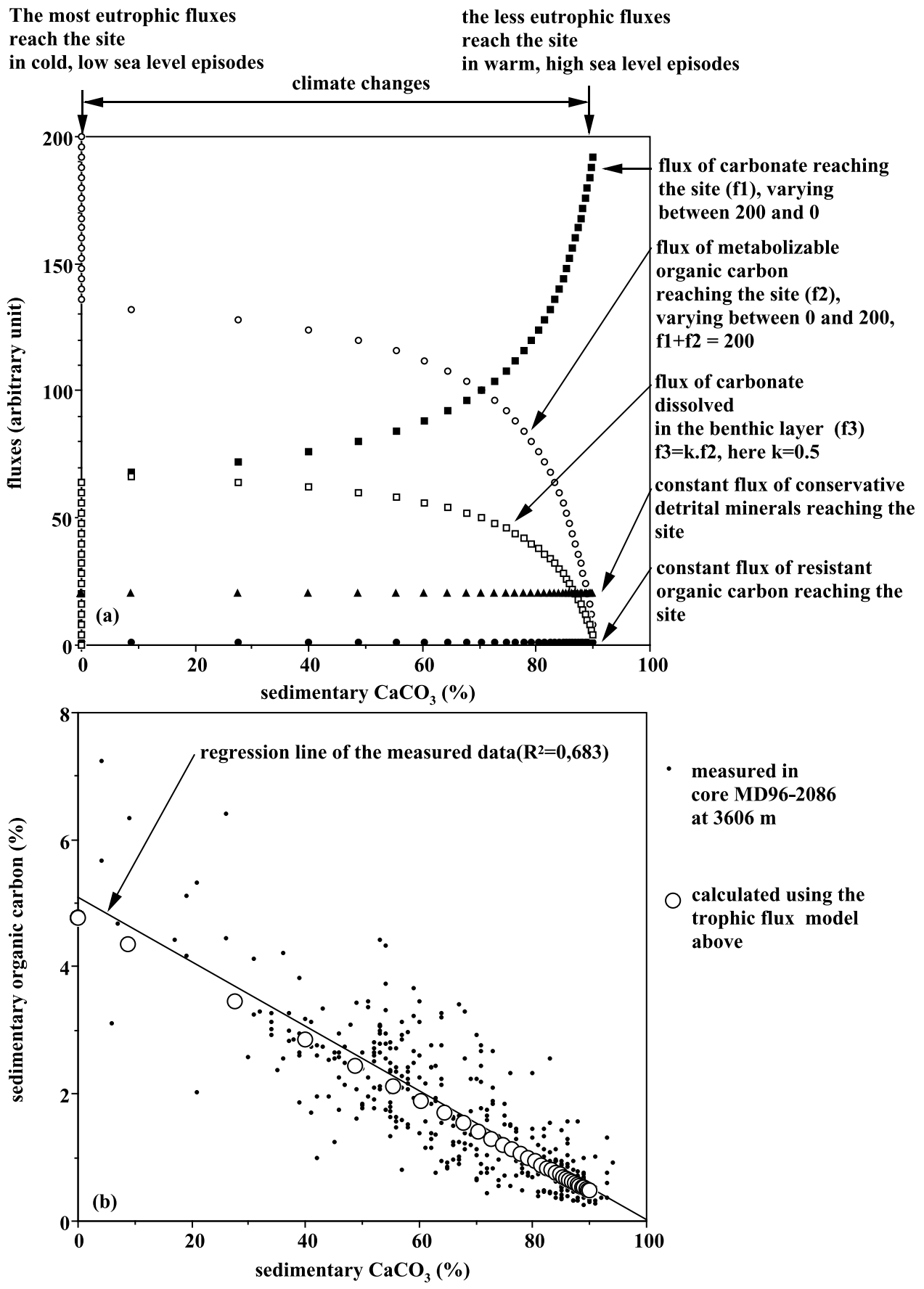

Figure 8. Simulation of the proposed interpretation in a simple nonparameterized numerical flux model. Fluxes (model input) are represented versus the carbonate content of the fossilized sediment (model output). Fluxes of carbonate and of metabolizable organic carbon vary from 0 to 200 (increment 1, arbitrary units) and from 200 to 0 , respectively. The limits represent a hypothetical evolution from the most to the least eutrophic conditions seen by the core site. The dissolved carbonate flux results from benthic degradation of metabolizable organic matter via oxic respiration. (a) All fluxes are represented versus calculated resulting carbonate contents in sediments. For the most eutrophic situation, complete dissolution of carbonate may be modeled. (b) The modeled organic carbon contents are linearly related to the modeled carbonate contents, as observed in the empirical data set.

constant conservative (refractory) fluxes. The most eutrophic flux conditions are arbitrarily represented on the left side of Figure $8 \mathrm{a}$ by a flux of 200 arbitrary units of metabolizable organic matter reaching the site (f2), while the carbonate flux (f1) is zero. In the case of the migration of the upwelling cell landward during a climate transition from a cold (low sea stand) to a warm (high sea stand) state, the surface waters above the core site progressively evolve toward being less eutrophic. During the same transition, the flux of metabolizable organic matter in the model decreases 
as the upwelling cell moves shoreward while the flux of carbonate increases due to a shift from diatom-dominated plankton in eutrophic conditions to coccolithophorid domination in less nutrient-rich waters (the sum of both fluxes is assumed to be constant). All or part of the carbonate flux is dissolved (f3) in the model as a consequence of oxic degradation of organic matter in the benthic layer. Here $\mathrm{f3}$ is assumed to be $50 \%$ of $\mathrm{f} 2$ ( $\mathrm{f} 3=\mathrm{k} . \mathrm{f} 2$ with $\mathrm{k}=0.5$ ). As a result, the contents of resistant organic matter and of all other conservative elements in the buried sediments vary as linear functions of the carbonate concentration, as shown in Figure $8 \mathrm{~b}$, where the modeled organic carbon contents are plotted together with the measured $\mathrm{C}_{\text {org }}$ values. We neglect biogenic opal in the model because sedimentary silicon occurs largely as an elemental component of detrital minerals at our core site. This does not mean that production of opal is not important, especially under the most eutrophic conditions, but only that it is poorly preserved in sediments. Thus, modeled concentrations of other parameters in the sediments on the deep slope would not change whether or not an opal flux was introduced in the model.

\section{Conclusion}

[33] This study has shown that very organic-rich pelagic sediments were deposited at great depth on an open wellventilated continental margin, free of anoxic or stagnant basin conditions. Such occurrences are rare in the ocean and reflect the collective influences of high productivity, an associated enhanced export flux of organic carbon, low terrigenous dilution and severe calcite dissolution. The latter results from organic matter remineralization in the sediments possibly amplified by periodic exposure to imported bottom waters that are more corrosive with respect to carbonate.

[34] We suggest that, mainly because of climate-related sea level changes, the sedimentary fluxes that reach deep slope sites off southwest Africa derive from more or less eutrophic conditions. The upwelling regimes that produce eutrophic conditions are located closer to such deep-slope sites during sea level low stands in glacial periods than during highstands in warm intervals. Thus, organic matter delivery to the deep slope is strengthened by the more eutrophic conditions that prevail in overlying surface waters during cold episodes. At such times, metabolizable organic matter is more efficiently transferred to the deep seafloor due to a larger $f$ ratio (total primary productivity/ export productivity below the surface mixed layer) and a shorter residence time in the oxic water column. An important consequence of this is that particulate carbonates on the bottom may be partly or entirely dissolved by the oxic degradation of the metabolizable organic matter arriving at the seafloor. This leads to the relative concentration of resistant organic matter, as well as the other conservative detrital fractions. Finally, we note that the probability that such organic-rich facies occurred in the past in equivalent oceanographic settings at the edge of large oceanic basins should be carefully considered in deep offshore exploration.

[35] Acknowledgments. This study was mainly carried out within the context of the International Marine Global Change Study (IMAGES).
Major support to the R/V Marion-Dufresne IMAGES II cruise came from France and Germany. We thank the Centre National de la Recherche Scientifique (CNRS-INSU), NERC, and the Natural Sciences and Engineering Research Council of Canada for their support of postcruise studies. Some of the results presented in this paper were obtained in the context of Groupement de Recherche PALEOPRO of the CNRS.

\section{References}

Altabet, M. A., R. Francois, D. W. Murray, and W. L. Prell, Climate-related variations in denitrification in the Arabian Sea from sediment ${ }^{15} \mathrm{~N} /{ }^{14} \mathrm{~N}$ ratios, Nature, 373, -, 1995.

Berger, W. H., and A. Soutar, Preservation of plankton shells in an anaerobic basin off California, Geol. Soc. Am. Bull., 81, 275-282, 1970.

Berger, W. H., and G. Wefer, Central themes of South Atlantic circulation, in The South Atlantic: Present and Past Circulation, edited by G. Wefer et al., pp. 1-11, Springer-Verlag, New York, 1996.

Bertrand, P., and E. Lallier-Verges, Past sedimentary organic matter accumulation and degradation controlled by productivity, Nature, 364, 786788, 1993.

Bertrand, P., T. F. Pedersen, P. Martinez, S. E. Calvert, and G. Shimmield, Sea level impact on nutrient cycling in coastal upwelling areas during deglaciation: Evidence from nitrogen isotopes, Global Biogeochem. Cycles, 14, 341-355, 2000

Bertrand, P., J. Giraudeau, B. Malaizé, P. Martinez, M. Gallinari, T. F. Pedersen, C. Pierre, and M. T. Vénec-Peyré, Occurrence of an exceptional carbonate dissolution episode during early glacial isotope stage 6 in the southeastern Atlantic, Mar. Geol., 180, 235-248, 2002.

Bickert, T., and G. Wefer, Late Quaternary deep water circulation in the South Atlantic, in The South Atlantic: Present and Past Circulation, edited by G. Wefer et al., pp. 599-620, Springer-Verlag, New York, 1996.

Bickert, T., and G. Wefer, South Atlantic, and benthic foraminifer $\delta^{13} \mathrm{C}$ deviations: Implications for reconstructing the late Quaternary deep-water circulation, Deep Sea Res., Part II, 46, 437-452, 1999.

Crusius, J., S. E. Calvert, T. F. Pedersen, and D. Sage, Rhenium and molybdenum enrichments in sediments as indicators of oxic, suboxic and sulfidic condition of deposition, Earth Planet. Sci. Lett., 145, 6578, 1996.

de Graciansky, P. C., P. C. Deroo, J. P. Herbin, L. Montadert, C. Müller, A. Schaaf, and J. Sigal, Ocean-wide stagnation episode in the late Cretaceous, Nature, 308, 346-349, 1984.

Demaison, G., and G. T. Moore, Anoxic environments and oil source bed genesis, AAPG Bull., 64, 1179-1209, 1980.

Derenne, S., C. Largeau, E. Casadevall, C. Berkaloff, and B. Rousseau, Chemical evidence of kerogen formation in source rocks and oil shales via selective preservation of thin resistant outer walls of microalgae: Origin of ultralaminae, Geochim. Cosmochim. Acta, 55, 1041-1051, 1990 .

Diekmann, B., R. Petschick, F. X. Gingele, D. Fütterer, A. Abelmann, U. Brathauer, R. Gersonde, and A. Mackensen, Clay mineral fluctuations in late Quaternary sediments of the southeastern South Atlantic: Implications for past changes of deep water advection, in The South Atlantic: Present and Past Circulation, edited by G. Wefer et al., pp. 621-644, Springer-Verlag, New York, 1996.

Diester-Haas, L., P. A. Meyers, and P. Rothe, The Benguela Current and associated upwelling on the southwest African margin: A synthesis of the Neogene-Quaternary sediment record at DSDP 362 and 532, in Upwelling Systems: Evolution Since the Early Miocene, edited by C. P. Summerhayes et al., Geol. Soc. Spec. Publ., 64, 331-342, 1992.

Duplessy, J.-C., N. J. Shackleton, R. G. Fairbanks, L. Labeyrie, D. Oppo, and N. Kallel, Deep-water source variations during the last climatic cycle and their impact on the global deep-water circulation, Paleoceanography, 3, 343-360, 1988 .

Duplessy, J.-C., L. Labeyrie, M. Paterne, S. Hovine, T. Fichefet, J. Duprat, and M. Labracherie, High latitude deep water sources during the Last Glacial Maximum and the intensity of the global oceanic circulation, in The South Atlantic: Present and Past Circulation, edited by G. Wefer et al., pp. 445-460, Springer-Verlag, New York, 1996.

Eppley, R. W., and B. J. Peterson, Particulate organic matter flux and planktonic new production in the deep ocean, Nature, 282, 677-680, 1979.

Espitalié, J., G. Deroo, and F. Marquis, La pyrolyse Rock-Eval et ses applications; première partie, Rev. Inst. Fr. Pet., 40, 563-579, 1985a.

Espitalié, J., G. Deroo, and F. Marquis, La pyrolyse Rock-Eval et ses applications; troisième partie, Rev. Inst. franç. Pétrole, 40, 755-784, 1985 b.

Farrell, J. W., T. F. Pedersen, S. E. Calvert, and B. Nielsen, Glacial-interglacial changes in surface nutrient utilization in the equatorial Pacific sediments, Nature, 377, 514-517, 1995. 
Ganeshram, R. S., T. F. Pedersen, S. E. Calvert, and J. W. Murray, Large changes in oceanic nutrient inventories from glacial to interglacial periods, Nature, 376, 755-758, 1995.

Ganeshram, R. S., S. E. Calvert, T. F. Pedersen, and G. L. Cowie, Factors controlling the burial of organic carbon in laminated and bioturbated sediments off NW Mexico:Implications for hydrocarbon preservation, Geochim. Cosmochim. Acta, 63, 1723-1734, 1999.

Hales, B., S. Emerson, and A. D. Dummy, Respiration and dissolution in the sediments of the western North Atlantic: Estimates from models of in situ microelectrode measurements of pore water oxygen and $\mathrm{pH}$, Deep Sea Res., Part I, 41, 695-719, 1994

Helz, G. R., C. V. Miller, J. M. Charnock, J. F. W. Mosselmans, R. A. D. Pattrick, C. D. Garner, and D. J. Vaughan, Mechanism of molybdenum removal from the sea and its concentration in black shales: EXAFS evidence, Geochim. Cosmochim. Acta, 60, 3631-3642, 1996.

Holmes, M. E., P. J. Müller, R. Schneider, M. Segl, and G. Wefer, Spatial variations in euphotic zone nitrate utilization based on $\delta^{15} \mathrm{~N}$ in surface sediments, Geo Mar. Lett., 18, 58-65, 1998.

Huc, A. Y., Aspects of depositional processes of organic matter in sedimentary basins, Org. Geochem., 13, 433-443, 1988.

Huc, A. Y., P. Bertrand, D. A. V. Stow, J. Gayet, and M. Vandenbroucke, Organic sedimentation in deep offshore settings: the Quaternary sediment approach, Mar. Pet. Geol., 18, 513-517, 2001

Hutchings, L., G. C. Pitcher, T. A. Probyn, and G. W. Bayley, The chemical and biological consequences of coastal upwelling, in Upwelling in the Ocean: Modern Processes and Ancient Records, edited by C. P. Summerhayes et al., pp. 65-81, John Wiley, New York, 1995.

Keil, R. G., D. B. Montluçon, F. G. Prahl, and J. L. Hedges, Sorptive preservation of labile organic matter in marine sediments, Nature, 370 , $549-552,1994$.

Kirst, G., P. J. Müller, R. R. Schneider, I. von Storch, and G. Wefer, Late Quaternary temperature variability in the Benguela Current system derived from alkenones, Quat. Res., 52, 92-103, 1999.

Lange, C. B., W. H. Berger, H. L. Lin, and G. Wefer, The early Matuyama diatom maximum off SW Africa, Benguela Current System (ODP leg 175), Mar. Geol., 161, 93-114, 1999.

Langford, F. F., and M. M. Blanc-Valleron, Interpreting Rock-Eval pyrolysis data using graphs of pyrolizable hydrocarbons vs. total organic carbon, AAPG Bull., 74, 799-804, 1990.

Lutjeharms, J. R. E., The exchange of water between the south Indian and South Atlantic Oceans, in The South Atlantic: Present and Past Circulation, edited by G. Wefer et al., pp. 125-162, Springer-Verlag, New York, 1996

Martinez, P., P. Bertrand, I. Bouloubassi, G. Bareille, G. Shimmield, B. Vautravers, F. Grousset, S. Guichard, Y. Ternois, and M.-A. Sicre, An integrated view of inorganic and organic biogeochemical indicators of palaeoproductivity changes in a coastal upwelling area, Org. Geochem., 24, 411-420, 1996.

Miller, J. R., and G. L. Russel, Ocean heat transport during the Last Glacial Maximum, Paleoceanography, 4, 141-155, 1989

Oppo, D. W., and R. G. Fairbanks, Atlantic Ocean thermohaline circulation over the last 150,000 years: Relationship to climate and atmospheric $\mathrm{CO}_{2}$, Paleoceanography, 5, 277-288, 1990.

Oppo, D. W., R. G. Fairbanks, A. L. Gordon, and N. J. Shackleton, Late Pleistocene Southern Ocean $\delta^{13} \mathrm{C}$ variability, Paleoceanography, 5, 4354, 1990.

Pedersen, T. F., and S. E. Calvert, Anoxia versus productivity: What controls the formation of organic-rich sediments and sedimentary rocks?, AAPG Bull., 74, 454-466, 1990.

Peinert, R., B. von Bodungen, and V. S. Smetacek, Food web structure and loss rate, in Productivity of the Ocean: Present and Past, edited by W. H.
Berger, V. S. Smetacek, and G. Wefer, pp. 35-48, John Wiley, New York, 1989

Prakash Babu, C., H.-J. Brumsack, and B. Schnetger, Distribution of organic carbon in surface sediments along the eastern Arabian Sea: A revisit, Mar. Geol., 162, 91-103, 1999.

Ramanampisoa, L., and J.-R. Disnar, Primary control of paleoproduction on organic matter preservation and accumulation in the Kimmeridge rocks of Yorkshire (UK), Org. Geochem., 21, 1153-1167, 1994.

Ransom, B., R. H. Bennett, R. Baerwald, and K. Shea, TEM study of in situ organic matter on continental margins: occurrence and the "monolayer" hypothesis, Mar. Geol., 138, 1-9, 1997.

Sackett, W. M., Stable carbon isotope studies on organic matter in the marine environment, in Handbook of Environmental Isotope Geochemistry, edited by A. P. Fritz and J.-C. Fontes, pp. 139-169, Elsevier Sci., New York, 1989.

Sarnthein, M., K. Winn, S. Jung, J.-C. Duplessy, L. Labeyrie, H. Erlenkeuser, and G. Ganssen, Changes in east Atlantic deepwater circulation over the last 30,000 years: Eight time slice reconstructions, Paleoceanography, 9, 209-267, 1994

Schmiedl, G., and A. Mackensen, Late Quaternary paleoproductivity and deep water circulation in the Eastern South Atlantic Ocean: Evidence from benthic foraminifera, Palaeogeogr. Palaeoclimatol. Palaeoecol., 130, 43-80, 1997.

Shannon, L. V., and G. Nelson, The Benguela: Large features and processes and system variability, in The South Atlantic: Present and Past Circulation, edited by G. Wefer et al., pp. 163-210, Springer-Verlag, New York, 1996.

Stow, D. V. A., South Atlantic organic-rich sediments: facies, processes and environments of deposition, in Marine Petroleum Source Rocks, edited by J. Brooks and A. J. Fleet, Geol. Soc. Spec. Publ., 287-299, 1987.

Summerhayes, C. P., D. Kroon, A. Rosell-Melé, R. W. Jordan, H. Schrader, R. Hearn, J. Villanueva, J. O. Grimalt, and G. Eglington, Variability in the Benguela Current upwelling system over the past 70,000 years, Prog. Oceanogr., 35, 207-251, 1995.

P. Bertrand, X. Giraud, D. Massias, and J. Villanueva, Departement de Géologie et Océanographie, UMR-CNRS 5805, Université de Bordeaux I, Avenue des Facultés, 33405 Talence Cedex, France. (Bertrand@geocean. u-bordeaux.fr)

A. Y. Huc, Institut Français du Pétrole, Avenue de Bois Préau, BP311, 92506 Rueil Malmaison Cedex, France.

E. Lallier-Verges and J. R. Disnar, Sédimentologie et Diagenèse de la Matière Organique, UMR 6531, Université d'Orléans, 45067 Orléans, France.

T. F. Pedersen, Oceanography, Earth and Ocean Sciences, University of British Columbia, 6270, University Boulevard, Vancouver, B. C., Canada, V6T $1 Z 4$.

C. Pierre, Laboratoire d'Océanographie Dynamique et de Climatologie, Université Pierre et Marie Curie, 4 Place Jussieu, Case 100, 75252 Paris Cedex 05, France.

R. Schneider, Fachbereicht Geowissenschaften, Universität Bremen, Postfach 330 440, 28334 Bremen, Germany.

G. Shimmield, Dunstaffnage Marine Laboratory, P. O. Box 3, Oban, PA34 4AD, UK.

N. Tribovillard, Sédimentologie et Géodynamique, UMR-CNRS 8577 , Université de Lille 1, 59655 Villeneuve d'Ascq cedex, France.

M.-T. Vénec-Peyré, Muséum National d'Histoire Naturelle, 8 rue Buffon, 75005 Paris Cedex, France. 